\title{
Effects of different day length and wind conditions to the seedling growth performance of Phragmites australis
}

\author{
Mun Gi Hong ${ }^{1}$, Bo Eun $\mathrm{Nam}^{2}$ and Jae Geun Kim ${ }^{2,3^{*}}$
}

\begin{abstract}
Background: To understand shade and wind effects on seedling traits of common reed (Phragmites australis), we conducted a mesocosm experiment manipulating day length (10 h daytime a day as open canopy conditions or $6 \mathrm{~h}$ daytime a day as partially closed canopy conditions) and wind speed $(0 \mathrm{~m} / \mathrm{s}$ as windless conditions or $4 \mathrm{~m} / \mathrm{s}$ as windy conditions).

Results: Most values of functional traits of leaf blades, culms, and biomass production of $P$. australis were higher under long day length. In particular, we found sole positive effects of long day length in several functional traits such as internode and leaf blade lengths and the values of above-ground dry weight (DW), rhizome DW, and total DW. Wind-induced effects on functional traits were different depending on functional traits. Wind contributed to relatively low values of chlorophyll contents, angles between leaf blades, mean culm height, and maximum culm height. In contrast, wind contributed to relatively high values of culm density and below-ground DW.
\end{abstract}

Conclusions: Although wind appeared to inhibit the vertical growth of $P$. australis through physiological and morphological changes in leaf blades, it seemed that $P$. australis might compensate the inhibited vertical growth with increased horizontal growth such as more numerous culms, indicating a highly adaptive characteristic of $P$. australis in terms of phenotypic plasticity under windy environments.

Keywords: Canopy openness, Common reed, Leaf blade revolving, Microclimate, Phenotypic plasticity

\section{Background}

Common reed (Phragmites australis [Cav.] Trin. ex Steud.) is a cosmopolitan species prevailing in wetland ecosystems over continents (Clevering et al. 2001; Köbbing et al. 2013; Hong et al. 2019). Phragmites australis shows not only such horizontally broad occurrences but also vertically wide distributions from montane fens with high altitude to salt marshes of over 25\% in salinity (Karunaratne et al. 2003; Hong and Kim 2012), indicating highly adaptive capacities

\footnotetext{
* Correspondence: jaegkim@snu.ac.kr

2Department of Biology Education, Seoul National University, Seoul 08826,

Republic of Korea

${ }^{3}$ Center for Education Research, Seoul National University, Seoul 08826, Republic of Korea

Full list of author information is available at the end of the article
}

and tolerances in wetland ecosystems (Engloner 2009). Such characteristics may enable $P$. australis to importantly act in various types of wetland ecosystems such as an ecosystem engineer in floating marshes (Hong et al. 2018), a wind and wave breaker in coastal marshes (Hansson and Graneli 1984), and as a water purifier in constructed marshes (Vymazal 2011; Nam et al. 2018).

During the last several decades, researchers have performed numerous studies on the growth responses of $P$. australis in relation to various types of environments to deeply understand the ecology of $P$. australis based on the practical usability and ecological value of $P$. australis in wetland ecosystems (Haslam 1969; Engloner 2009; Vymazal 2011; Hong et al. 2018). In particular, a great deal of empirical study has focused on functional

(c) The Author(s). 2021 Open Access This article is licensed under a Creative Commons Attribution 4.0 International License, which permits use, sharing, adaptation, distribution and reproduction in any medium or format, as long as you give appropriate credit to the original author(s) and the source, provide a link to the Creative Commons licence, and indicate if changes were made. The images or other third party material in this article are included in the article's Creative Commons licence, unless indicated otherwise in a credit line to the material. If material is not included in the article's Creative Commons licence and your intended use is not permitted by statutory regulation or exceeds the permitted use, you will need to obtain permission directly from the copyright holder. To view a copy of this licence, visit http://creativecommons.org/licenses/by/4.0/ 
traits of $P$. australis in responses to nutrients such as nitrogen and phosphorus and disturbance regimes such as flood (including wind-induced wave) and salinity (Armstrong et al. 1999; Engloner 2009; Vymazal 2011).

In addition to such major environmental determinants of functional traits, day length and wind speed may also be environmentally important factors for $P$. australis as microclimates (Baldi 1999; Asaeda and Karunaratne 2000). In particular, different day length may affect $P$. australis in terms of phenology and morphology (Clevering et al. 2001). Wind speed may also affect $P$. australis directly (e.g., evapotranspiration, phenotypic plasticity, pollination, and seed dispersal) as well as indirectly (e.g., convective gas-flow, fire event, litter breakdown, and propagule drift) (Thompson and Shay 1985; Armstrong and Armstrong 1991; Nilsson et al. 1991; Baldi 1999; Brisson et al. 2008).

Despite such importance of both microclimatic factors for growth performances of $P$. australis in wetland ecosystems, available literatures on effects of day length and/or wind speed on functional traits of $P$. australis are still limited. Moreover, most researchers have investigated on effects of different day length and/or wind speed to $P$. australis particularly on mature plants in natural wetlands under environmentally complicated conditions (Baldi 1999; Clevering et al. 2001; Karunaratne et al. 2003). Even though both day length and wind can be influential factors for $P$. australis not only in mature plant stage but also in seedling stage, empirical evidence for effects of different day length and/or wind speed on $P$. australis seedlings particularly under controlled environments is lacking yet.

In the present study, we firstly tried to investigate the effects of different day length and wind speed as microclimates on functional traits of $P$. australis seedlings. To eliminate possible confounding effects by other environmental factors that are common in natural wetlands such as nutrients and flood, we conducted a controlled mesocosm experiment only manipulating day length and wind speed in a greenhouse. We examined differences in functional traits of $P$. australis such as growth parameters depending on day length and wind speed. In particular, we also compared both chlorophyll contents as a physiological parameter and angles between leaf blades as a geometrical parameter to verify wind-induced effects on $P$. australis seedlings.

\section{Results}

Effects of different day length and wind speed on functional traits of $P$. australis

Based on the result from two-way ANOVA, different day length made significant differences in most functional traits of leaf blades (chlorophyll contents, angles between leaf blades, and leaf blade length), culms (culm density, internode length, mean culm height, and maximum culm height), and biomass production (aboveground dry weight (AGDW), below ground dry weight (BGDW), rhizome DW, and total dry weight (TDW)) (Table 1). In contrast, different wind speed significantly affected chlorophyll contents $(p<.05)$, leaf blade length $(p<.001)$, and mean culm height $(p<.05)$ only (Table 1$)$. We also found some interactive effects between day length and wind speed on leaf blade length $(p<.05)$ and root dry weight $(p<.1)$.

\section{Leaf blade functional traits}

Both different day length and wind speed significantly affected most functional traits of leaf blades only except leaf blade number (Fig. 1). Day length and wind speed showed opposite effects on both chlorophyll contents and angles between leaf blades. Both chlorophyll contents $\left(\mathrm{SD}, 37.2 \pm 0.3 \mu \mathrm{g} / \mathrm{cm}^{2}\right.$; SDW, $36.4 \pm 0.3 \mu \mathrm{g} / \mathrm{cm}^{2}$; $\left.\mathrm{LD}, 38.2 \pm 0.3 \mu \mathrm{g} / \mathrm{cm}^{2} ; \mathrm{LDW}, 37.6 \pm 0.3 \mu \mathrm{g} / \mathrm{cm}^{2}\right)$ and angles between leaf blades (SD, $99 \pm 3^{\circ}$; SDW, $89 \pm 4^{\circ}$;

Table 1 The result of $F$ values from two-way ANOVA on functional traits of $P$. australis

\begin{tabular}{|c|c|c|c|c|c|c|c|c|}
\hline Variables factors & $\begin{array}{l}\text { Chlorophyll } \\
\text { contents }\end{array}$ & $\begin{array}{l}\text { Leaf blade } \\
\text { angle }\end{array}$ & $\begin{array}{l}\text { Leaf blade } \\
\text { number }\end{array}$ & $\begin{array}{l}\text { Leaf blade } \\
\text { length }\end{array}$ & $\begin{array}{l}\text { Internode } \\
\text { number }\end{array}$ & $\begin{array}{l}\text { Internode } \\
\text { length }\end{array}$ & $\begin{array}{l}\text { Culm } \\
\text { density }\end{array}$ & $\begin{array}{l}\text { Culm } \\
\text { diameter }\end{array}$ \\
\hline Day-length $(d f=1)$ & $3.094^{+}$ & $4.432 *$ & 2.919 & $17.200 * * *$ & 1.636 & $6.631^{*}$ & $3.322^{+}$ & 0.611 \\
\hline Wind speed $(d f=1)$ & 1.487 & $4.947^{*}$ & 0.572 & 0.076 & $4.545^{+}$ & 0.384 & 0.831 & 0.391 \\
\hline Day-length $\times$ wind speed $(d f=1)$ & 0.027 & 0.674 & 0.007 & 1.027 & 0.000 & 0.129 & 0.033 & 0.611 \\
\hline Variable factors & $\begin{array}{l}\text { Mean culm } \\
\text { height }\end{array}$ & $\begin{array}{l}\text { Maximum culm } \\
\text { height }\end{array}$ & AGDW & BGDW & Rhizome DW & Root DW & TDW & $\begin{array}{l}\text { AGDW: } \\
\text { BGDW }\end{array}$ \\
\hline Day-length $(d f=1)$ & $4.529 *$ & $5.547^{*}$ & $21.400 * * *$ & $8.600 * *$ & $15.800^{* *}$ & 2.900 & $19.300^{* * *}$ & 0.659 \\
\hline Wind speed $(d f=1)$ & 2.430 & 1.803 & 0.848 & 0.061 & 0.200 & 0.752 & 0.253 & 0.791 \\
\hline Day-length $\times$ wind speed $(d f=1)$ & 0.198 & 0.528 & 0.919 & 1.011 & 0.714 & $3.174^{+}$ & 0.782 & $3.302^{+}$ \\
\hline
\end{tabular}

Bold letters with asterisks indicate statistical significance

AGDW Above-ground dry weight, BGDW Below-ground dry weight, TDW Total dry weight, DW Dry weight

${ }^{+} p<.1$

${ }^{*} p<.05$

${ }^{* *} p<.01$

*** $p<.001$ 

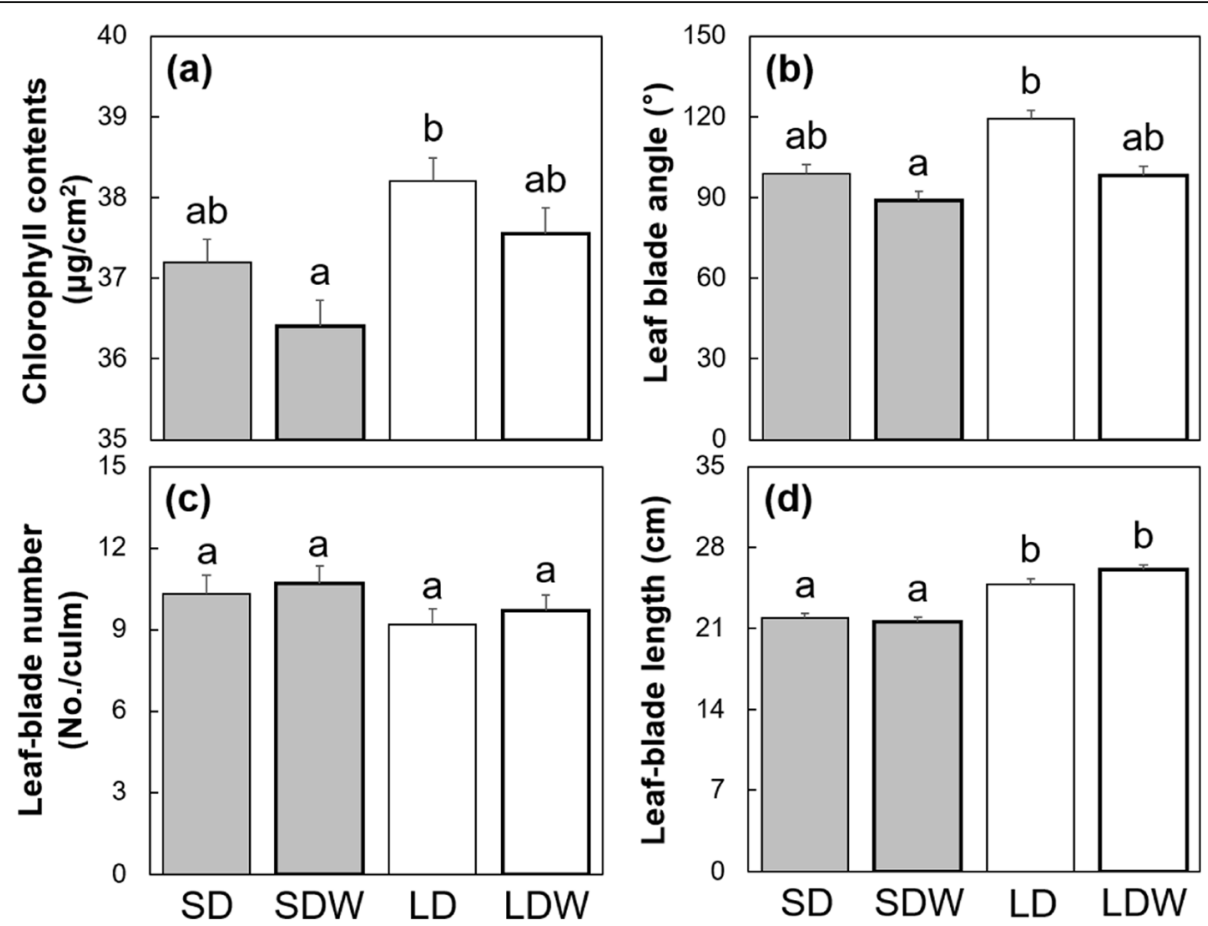

Fig. 1 Leaf blade functional traits depending on day length and wind speed ( $n=6$, mean \pm 1 SE). (a) Chlorophyll contents, (b) angles between leaf blades, (c) leaf blade number, (d) leaf blade length; SD, short day with wind speed $0 \mathrm{~m} / \mathrm{s}$; SDW, short day with wind speed $4 \mathrm{~m} / \mathrm{s}$; LD, long day with wind speed $0 \mathrm{~m} / \mathrm{s}$; LDW, long day with wind speed $4 \mathrm{~m} / \mathrm{s}$. Different alphabets indicate statistically different subgroups by Duncan's post hoc test $(p<.05)$. In the case of (a) chlorophyll contents, different sub-groups were statistically divided by Duncan's post hoc test with a different significance level, $p<0.1$

LD, $119 \pm 3^{\circ}$; LDW, $98 \pm 4^{\circ}$ ) were relatively high under long day length regardless of wind speed, whereas these values were relatively low under wind speed $4 \mathrm{~m} / \mathrm{s}$ regardless of day length (Fig. 1a and b). On the other hand, leaf blade length was relatively long under long day length and wind speed $4 \mathrm{~m} / \mathrm{s}$ (LDW) (Fig. 1d).

\section{Culm functional traits}

We found significant effects of different day length and wind speed on several functional traits of culms such as culm density and height, internode length, and maximum culm height (Fig. 2). In particular, culm density was relatively high under long day length with wind speed $4 \mathrm{~m} / \mathrm{s}$ (SD, $7.7 \pm 0.6 \mathrm{culms} /$ pot; SDW, $8.3 \pm 0.7$ culms/pot; LD, $9.2 \pm 0.2 \mathrm{culms} /$ pot; LDW, $10.2 \pm 0.7$ culms/pot). In the case of internode length, we found a sole positive effect of long day length only (Fig. 2d). On the other hand, both mean and maximum culm height also showed similar patterns with chlorophyll contents and angles between leaf blades. Long day length contributed relatively high values of mean culm height and maximum culm height, whereas wind speed $4 \mathrm{~m} / \mathrm{s}$ contributed to relatively low values of these functional traits (Fig. 2e and f).
In particular, the values of the maximum culm height were different depending on day length and wind speed. The highest value $(175 \pm 10 \mathrm{~cm})$ during the whole experimental period was measured under long day length and wind speed $0 \mathrm{~m} / \mathrm{s}$ at the $15^{\text {th }}$ week (Fig. 3). Similarly, at the end of the experiment (the $18^{\text {th }}$ week), the highest value also was obtained under long day length and wind speed $0 \mathrm{~m} / \mathrm{s}(163 \pm 11 \mathrm{~cm})$. In contrast, the lowest value was found under short day length and wind speed $4 \mathrm{~m} / \mathrm{s}(135 \pm 6 \mathrm{~cm})$ (Fig. 3).

\section{Biomass production traits}

Most functional traits of biomass production only except AGDW:BGDW ratios showed significant differences among the experimental plots (Fig. 4). We found sole positive effects of long day length in some functional traits such as AGDW, rhizome DW, and TDW regardless of wind speed. We also detected interactive effects between day length and wind speed in other functional traits such as BGDW and root DW. The values of AGDW, rhizome DW, and TDW were relatively high under long day length regardless of wind. On the other hand, the interactive effects were more evident under long day length. We obtained the highest values of BGDW $(9.6 \pm 1.2 \mathrm{~g} / \mathrm{pot})$ and 

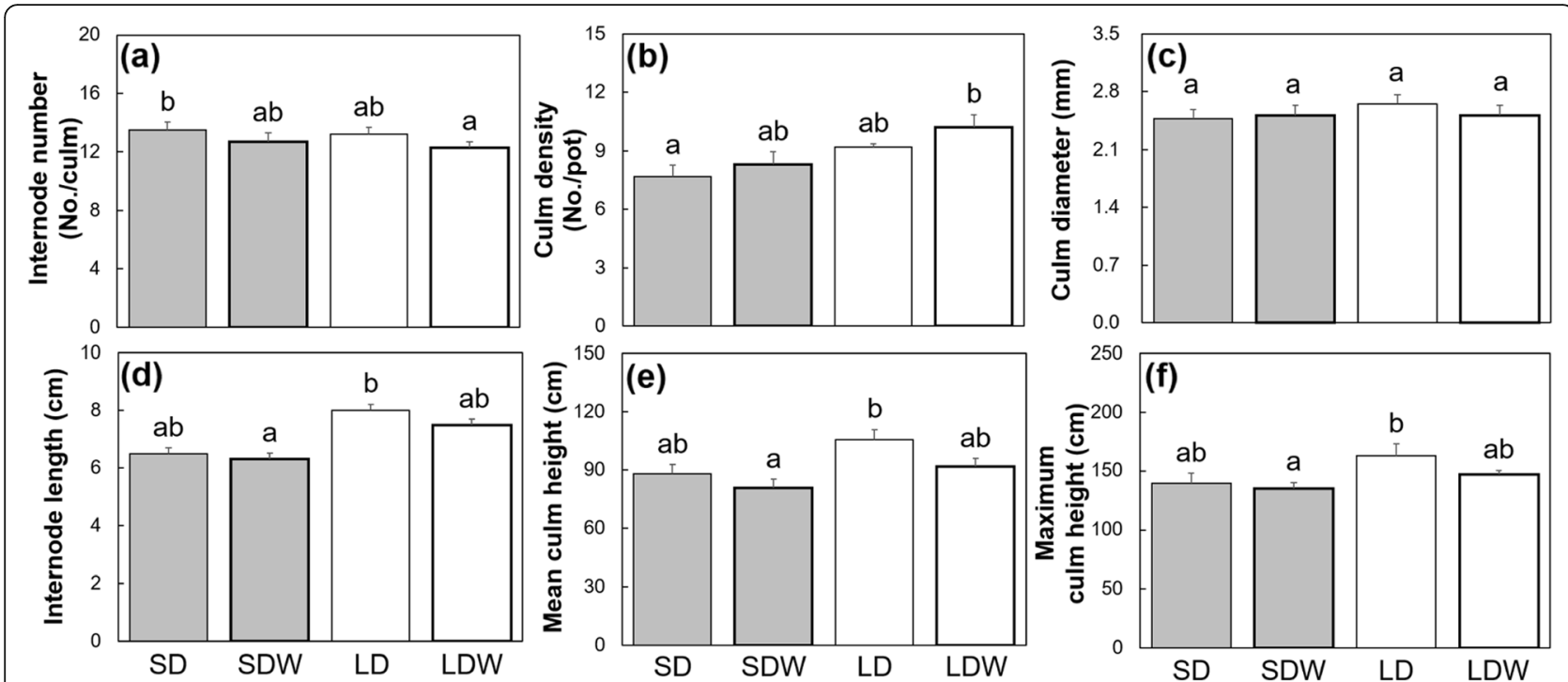

Fig. 2 Culm functional traits depending on day length and wind speed $(n=6$, mean \pm 1 SE). (a) Internode number, (b) culm density, (c) culm diameter, (d) internode length, (e) mean culm height, (f) maximum culm height; SD, short day with wind speed $0 \mathrm{~m} / \mathrm{s}$; SDW, short day with wind speed $4 \mathrm{~m} / \mathrm{s}$; LD, long day with wind speed $0 \mathrm{~m} / \mathrm{s}$; LDW, long day with wind speed $4 \mathrm{~m} / \mathrm{s}$. Different alphabets indicate statistically different subgroups by Duncan's post hoc test $(p<.05)$. In the cases of (a) internode number and (b) culm density, different sub-groups were statistically divided by Duncan's post hoc test with a different significance level, $p<0.1$

root DW $(4.8 \pm 1.0 \mathrm{~g} / \mathrm{pot})$ under long day-length with wind speed $4 \mathrm{~m} / \mathrm{s}$ (Fig. $4 \mathrm{~b}$ and e).

\section{Discussion}

\section{Day length effects on $P$. australis}

It has been abundantly reported that day length determines phenological traits of $P$. australis such as growth period length and flowering timing (Clevering et al. 2001; Karunaratne et al. 2003). In addition to such phenological traits, it has also been noted that day length also affects functional traits closely related to growth performances of $P$. australis such as culm height, density, and biomass production (Zhou et al. 2010; Hughes et al. 2016). In accordance with these previous studies, we also found big effects of different day length on $P$. australis functional traits. Most values of functional traits of leaf blades, culms, and biomass production were relatively high under long day length, indicating positive

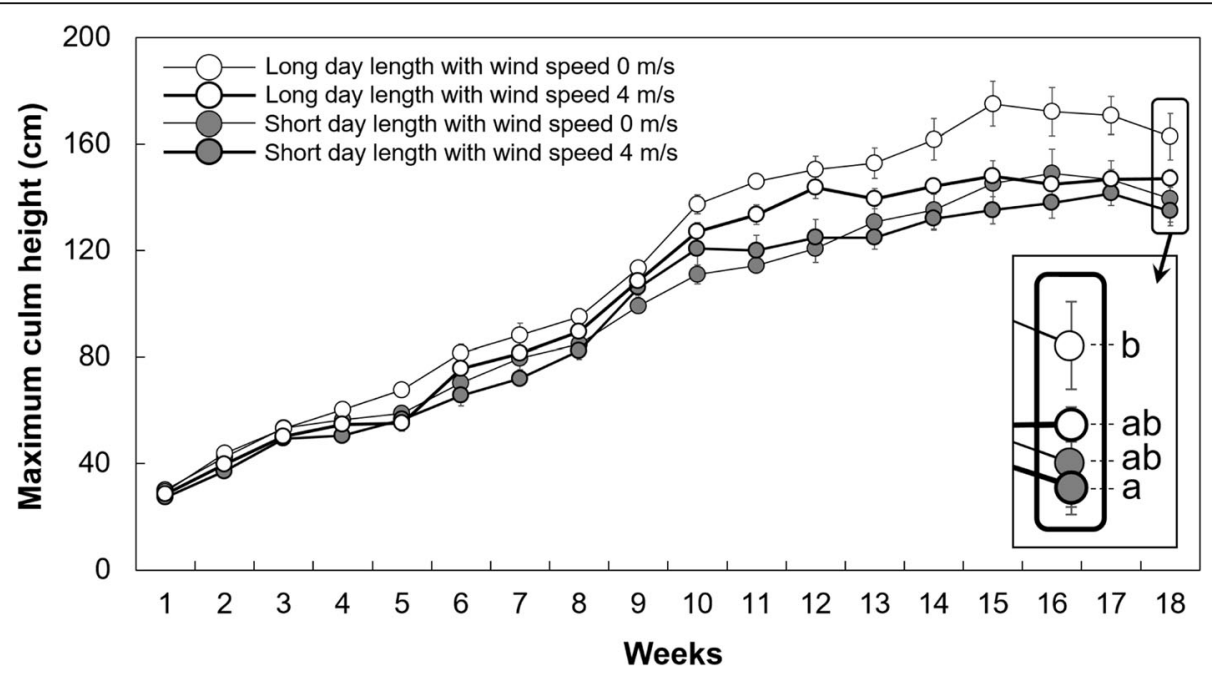

Fig. 3 Changes in maximum culm height of $P$. australis $(n=6$, mean \pm 1SD) depending on day length and wind speed during the experimental period (each $n=6$ ). Different alphabets on the values at the end of the experiment (the $18^{\text {th }}$ week) indicate statistically different sub-groups by Duncan's post hoc test $(p<.05)$ 

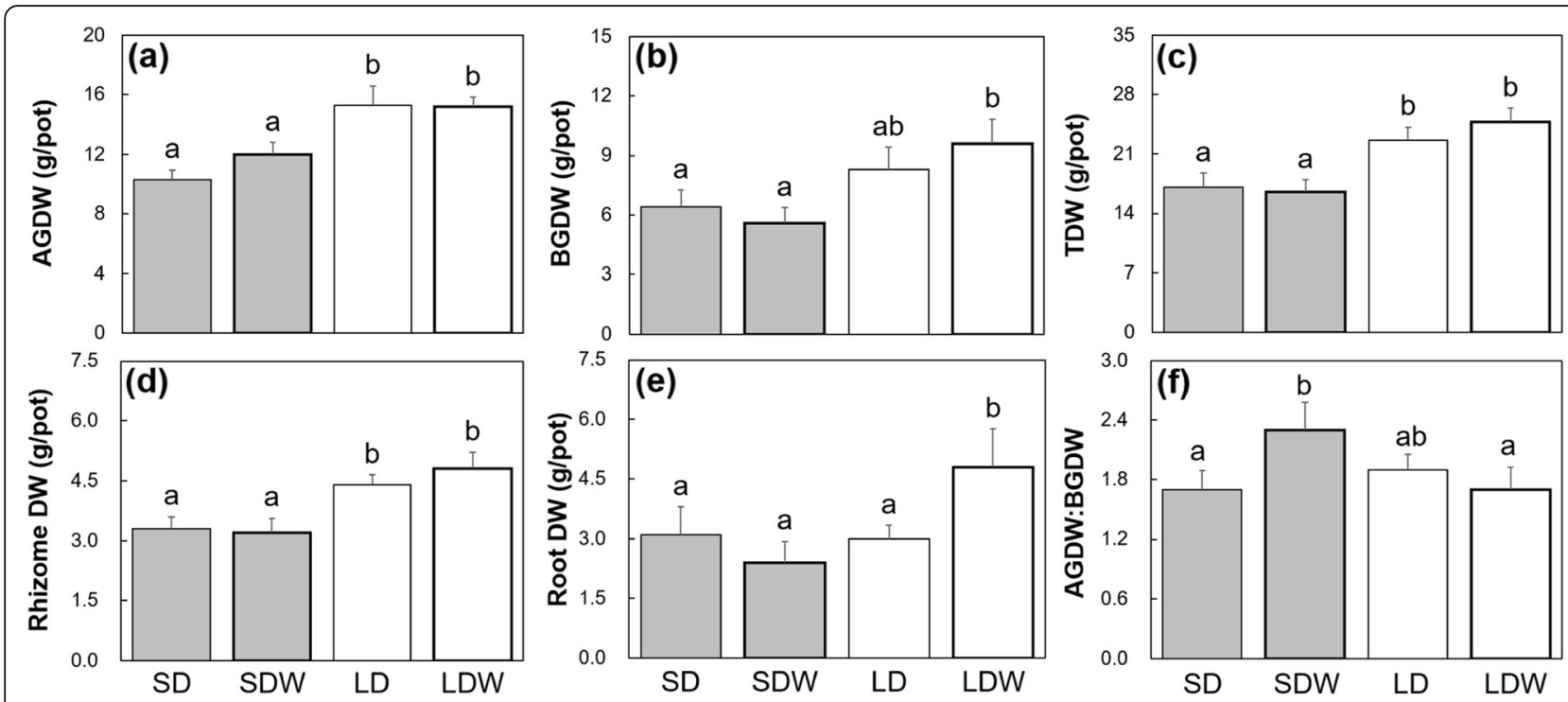

Fig. 4 Biomass production traits of $P$. australis depending on day length and wind speed ( $n=6$, mean $\pm 1 S E)$. (a) AGDW, (b) BGDW, (c) TDW, (d) rhizome DW, (e) root DW, (f) AGDW:BGDW; AGDW, above-ground dry weight; BGDW, below-ground dry weight; TDW, total dry weight; DW, dry weight; SD, short day with wind speed $0 \mathrm{~m} / \mathrm{s}$; SDW, short day with wind speed $4 \mathrm{~m} / \mathrm{s}$; LD, long day with wind speed $0 \mathrm{~m} / \mathrm{s}$; LDW, long day with wind speed $4 \mathrm{~m} / \mathrm{s}$. Different alphabets indicate statistically different subgroups by Duncan's post hoc test $(p<.05)$. In the cases of (e) root DW and (f) AGDW:BGDW, different sub-groups were statistically divided by Duncan's post hoc test with a different significance level, $p<0.1$

effects of long day length on overall growth performances of $P$. australis.

In particular, positive effects of long day length were more evident in the functional traits directly related to biomass production such as culm height and density, possibly indicating positive contributions of long day length to biomass production of $P$. australis (Clevering et al. 2001; Karunaratne et al. 2003; Zhou et al. 2010). In addition to such positive effects of long day length on biomass production, we also found another positive effect on a physiological parameter, chlorophyll contents (greenness). In our study, at the end of the experiment, $P$. australis exhibited relatively green leaf blades (i.e., higher chlorophyll contents) under long day length, probably indicating a potential for a longer growth period of $P$. australis under long day length. On the other hand, we found no effect of different day length on some functional traits that are indirectly related (or not related) to biomass production such as leaf blade number, internode number, culm diameter, and AGDW: BGDW ratio.

Higher growth performances of $P$. australis seedlings under longer day length possibly mean higher possibility of successful establishment in new sites via seed dispersal (Haslam 1975). Numerous studies have mostly attributed rapid expansions of $P$. australis to asexual reproductive organs such as rhizomes (Amsberry et al. 2000; Saltonstall 2002). By contrast, some other studies have reported that such rapid expansions could also be a consequence of seed dispersal and successful seedling establishment (Brisson et al. 2008; Belzile et al. 2010). In particular, some studies have also attributed such successful establishment of $P$. australis seedlings in new sites to enlarged day length due mainly to favorable local conditions of new sites such as open canopy as well as global warming (Clevering et al. 2001). Although we did not observe any panicle-bearing culm from our seedling experiment, we clearly found positive effects of long day length on overall growth performances of $P$. australis seedlings.

According to previous studies on distributional characteristics of $P$. australis, although this species usually shows a very wide range of distribution (Clevering and Lissner 1999; Clevering et al. 2001), P. australis appears to more frequently occur in lower latitude areas (and/or lower altitude). Presumably, short day length in higher latitude areas may limit short-term growth of $P$. australis seedlings as seen in our study as well as long-term establishment (Clevering et al. 2001; Karunaratne et al. 2003), probably explaining relatively few cases of $P$. australis occurrence in such high latitude areas. In cases of mountainous wetlands with high altitude, both too low temperatures for $P$. australis seedlings to winter and/or short day length possibly due to tree canopy cover may also disturb successful establishment of $P$. australis seedlings in such mountainous wetlands with high altitude.

\section{Wind effects on $P$. australis}

Wind is an important environmental factor for $P$. australis particularly in a rapid expansion over a long distance because $P$. australis is a wind-pollinated and dispersed 
species (Soons 2006; Belzile et al. 2010). In addition to the pollination and seed dispersal, wind is also important for propagule drift via wind-induced current or wave in both riparian and coastal wetlands (Nilsson et al. 1991). It was also noted that wind may partly affect nutrient dynamics in $P$. australis-dominated wetlands via facilitating litter breakdown and decomposition (Haslam 1989; ÁgostonSzabó and Dinka 2008).

On the other hand, some previous studies have noted that wind may directly affect population structure of $P$. australis. According to a previous study by Baldi (1999), $P$. australis made relatively short but many shoots particularly in edge areas under windy environments, indicating edge effect. In contrast, $P$. australis produced relatively tall but a small number of shoots in interior areas of the reed population under windless environments. It was also reported that such wind-induced differences in reed growth may contribute to make wetland environments more heterogeneous (Karstens et al. 2016), thereby providing various types of habitats for wetland fauna in wetlands (Baldi 2005).

In accordance with the observation by Baldi (1999), we also found such opposite results in terms of vertical and horizontal growth of $P$. australis depending on wind speed. Although we tested wind-induced effects on seedlings but not on mature plants, we also found such opposite results regardless of day length similar to those from the previous studies (Klötzli 1973; Baldi 1999). From our results, wind $(4 \mathrm{~m} / \mathrm{s}$ in our study) appeared to inhibit vertical growth of $P$. australis. Such inhibited vertical growth of $P$. australis seemed to be attributable to wind-induced changes in physiology as well as morphology (geometry) of leaf blades. There has been abundant evidence for wind-induced effects on morphology and physiology in other herbaceous species such as Brassica spp., Phaselous spp., Stellaria spp., and Brachypodium sp. (Jaffe and Forbes 1993; Emery et al. 1994; Murren and Pigliucci 2005; Nam et al. 2020).

In our study, angles between leaf blades were relatively low under windy conditions regardless of day length. It seemed that revolved leaf blades (i.e., angles between leaf blades were less than $180^{\circ}$ ) due to wind flow might shade each other. Notably, some revolved leaf blades were completely separated from culms and some leaf blades fell off even owing to wind flow at the end of the experiment. Such geometrical changes in leaf blades seemed likely to result in a decrease in chlorophyll contents under windy environments, indicating a potential for a decrease in photosynthesis (Lessmann et al. 2001). In addition, physically inclined plants by wind flow might be more likely to be shaded by other plants, also possibly resulting in an additional decrease in the vertical growth of $P$. australis (Baker et al. 2014).
In the current study, wind seemed to disturb the vertical growth of $P$. australis via both physiological and morphological changes. Instead, wind appeared to stimulate the horizontal growth of $P$. australis. Under windy environments, $P$. australis made shorter but more numerous shoots bearing longer leaf blades, indicating a compensation for the inhibited vertical growth via phenotypic plasticity (Baldi 1999; Liu et al. 2014). In addition, $P$. australis made more roots, thus more below-ground parts under windy conditions particularly under long day length in our study. Such a windinduced increase in below-ground parts including roots might also be a result from phenotypic plasticity of $P$. australis as a response to an increased evapotranspiration particularly in the experimental plots under long day length and wind (Whitehead and Luti 1962; Zhou et al. 2010). In fact, the taller the plants vertically grew, the more often we had to pour water to maintain the water level particularly in these experimental plots.

On the other hand, according to some previous studies (Takeda and Kurihara 1988; Vymazal 2011; Karstens et al. 2016), P. australis stands in shoresides (edge areas) play important roles not only as a wind and wave breaker preventing soil erosion through making dense stands but also as an ecosystem engineer stabilizing wetland edges via facilitating sediment deposition. In accordance with the previous studies, we also empirically verified such wind-induced contributions not only to dense stands of $P$. australis but also to a greater production (or more allocation) of below-ground parts particularly in edge areas. Notably, wind-induced responses of $P$. australis such as many shoots and more allocation into below-ground parts may confer more advantages on $P$. australis particularly in deep water wetlands via facilitating convective gas flow under low sediment redox potentials possibly coupled to high levels of phytotoxins (Armstrong et al. 1996; Asaeda et al. 2002).

\section{Concluding remarks}

Based on most values of the functional traits, P. australis exhibited a higher growth performance under long day length than short day length, evidently indicating that long day length is an important environmental factor for better growth of $P$. australis seedlings. In addition, there are sole positive effects of long day length in internode length and the values of above-ground dry weight (DW), rhizome DW, and total DW. In contrast, there is no negative effect of long day length on any functional trait of P. australis (Fig. 5).

On the other hand, wind-induced effects on functional traits of $P$. australis were different depending on functional traits. Wind contributed to relatively low values of chlorophyll contents, angles between leaf blades, and mean and maximum culm height. In contrast, wind 


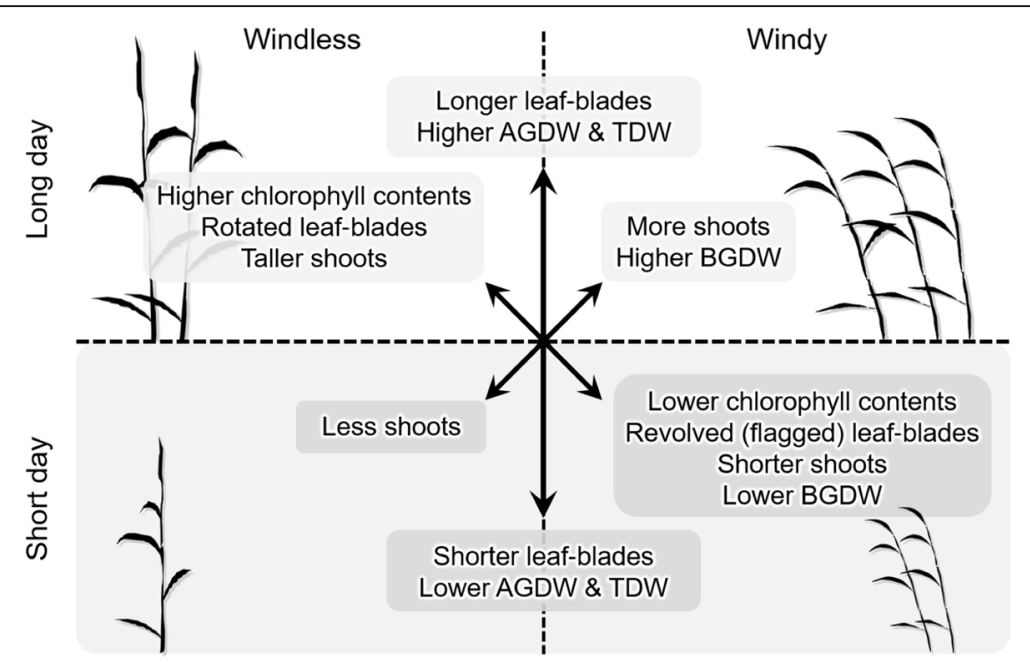

Fig. 5 A schematic diagram indicating wind and day length effects on functional traits of $P$. australis seedlings. AGDW, above-ground dry weight; BGDW, below-ground dry weight; TDW, total dry weight

contributed to relatively high values of leaf blade length, culm density, root DW, and below-ground DW particularly under long day length. From our results, although wind disturbed the vertical growth of $P$. australis through both physiological and morphological changes in leaf blades, it seemed that $P$. australis might compensate the inhibited vertical growth with increased horizontal growth such as more numerous culms and longer leaf blades, indicating a highly adaptive characteristic of $P$. australis in terms of phenotypic plasticity under windy environments. In addition, wind also appeared to stimulate $P$. australis to make more roots, thus more below-ground parts particularly under long day length, also showing phenotypic plasticity of $P$. australis (Fig. 5).

\section{Conclusions}

We confirmed substantial effects of both microclimatic factors on most functional traits of $P$. australis. Based on previous studies and our findings, different day length and wind speed seem to importantly affect not only seedling growth (i.e., phenotypic plasticity) and early establishment (i.e., population expansion) as short-term growth effects but also for population structure of $P$. australis as long-term effects (i.e., edge effect). From our study, we suggest that both day length and wind speed have to be additionally considered as important environmental determinants in further studies on growth performances of $P$. australis seedlings as well as mature plants in addition to other major environmental determinants such as nutrients and water level.

\section{Methods}

\section{Seedling preparation}

We chose $P$. australis seedlings as plant materials instead of culms or rhizomes to minimize possible effects of different carbohydrate contents in asexual organs on growth performances (Klimeš et al. 1999; Hong and Kim 2014). We collected seeds in a $P$. australis-dominated freshwater wetland of floating marsh type ( $37^{\circ} 27^{\prime}$, E $127^{\circ} 18^{\prime}$; about $30 \mathrm{~m}$ a.s.l.). In the sampling site, most $P$. australis shoots grew about $3 \mathrm{~m}$ in shoot height with about 30 shoots $/ \mathrm{m}^{2}$ and produced about $1 \mathrm{~kg} / \mathrm{m}^{2}$ in standing crop (Hong and Kim 2012; Hong et al. 2019). Although there were some shrub species such as Salix gracilistyla Miq. and Spiraea salicifolia L., P. australis was the tallest species in most areas within the sampling site.

To prepare $P$. australis seedlings, we carried the seeds to a laboratory in Seoul National University (N $37^{\circ} 27^{\prime}$, E $126^{\circ} 57^{\prime}$; about $120 \mathrm{~m}$ a.s.l.). Both the sampling site and the experimental site were similar in terms of climate (i.e., latitudes of both sites were similar and the distance between two sites were about $30 \mathrm{~km}$ ). Seeds were germinated on plastic trays (30 $\mathrm{cm}$ in width $\times 100 \mathrm{~cm}$ in length $\times 8 \mathrm{~cm}$ in height) that were filled with agricultural soil consisting of sand, vermiculate, zeolite, and granular fertilizer (Table S1) under $23{ }^{\circ} \mathrm{C} / 24 \mathrm{~h}$ light in a growth chamber. After the germination process, seedlings had been grown in a greenhouse for about 2 weeks until most seedlings reach about $30 \mathrm{~cm}$ in shoot height.

\section{Experimental design}

We prepared a total of 24 opaque plastic containers (20 $\mathrm{cm}$ in width $\times 20 \mathrm{~cm}$ in length $\times 20 \mathrm{~cm}$ in height) as individual experimental plots. We fully filled up the containers with the agricultural soil that was also used for the germination process. Then, a total of 24 seedlings of similar shoot height (about $30 \mathrm{~cm}$ ) were transplanted to the depth of about $3 \mathrm{~cm}$ in the center of each container. 
Right after the plantation, seedling height was $27.5 \pm 2.1$ $\mathrm{cm}$ (mean $\pm 1 \mathrm{SD})$. We maintained water level at $10 \mathrm{~cm}$ (i.e., the middle height of containers) below the soil surface. In particular, to eliminate any possible confounding effect due to different amounts of supplied water (i.e., possibly different amounts of nutrients) depending on different levels of evapotranspiration by different day length and wind speed, we used distilled water in maintaining the water level instead of tap water possibly containing nutrients.

We prepared a total of four different environmental combinations of day length and wind speed (two day length $\times$ two wind speed): short day length and wind speed $0 \mathrm{~m} / \mathrm{s}$, SD; short day length and wind speed $4 \mathrm{~m} / \mathrm{s}$, SDW; long day length and wind speed $0 \mathrm{~m} / \mathrm{s}$, LD; long day length and wind speed $4 \mathrm{~m} / \mathrm{s}$, LDW. Two different day length (12 containers for SD, $6 \mathrm{~h}$ from 10 a.m. to 4 p.m.; 12 containers for LD, 10 h from 8 a.m. to 6 p.m.) were maintained via shutting out solar radiation by using shading nets during the experimental period (18 weeks). We measured light intensity just above the reed canopy three times $\left(1^{\text {st }}, 9^{\text {th }}\right.$, and $17^{\text {th }}$ week) during the experimental period and there was no significant difference in the light intensity among the experimental plots of different experimental conditions regardless of measurement timings (Table S2).

The half (12 containers, six containers for SDW, and the other six containers for LDW) of the plots were placed in front of electric fans (fan blade $\varnothing=$ about 100 $\mathrm{cm}$ ) with the interval of $1.5 \mathrm{~m}$ between the containers and the electric fans as windy environments. Electric fans were turned on every hour and only last for $15 \mathrm{~min}$ using timer-control consents. During the experimental period of 18 weeks, electric fans have produced the wind speed about $4.0 \mathrm{~m} / \mathrm{s}$ (i.e., measured in front of plants) for 10 h/day (from 8 a.m. to 6 p.m.).

\section{Data collection and analyses} Leaf blade functional traits

After 18 weeks of growth period, we measured chlorophyll contents in leaf blades, angles between leaf blades, leaf blade number, and length as leaf blade functional traits. To determine these functional traits, we randomly selected five culms from each experimental plot. Chlorophyll contents as a greenness index of leaf blades were measured as a physiological parameter by using a portable chlorophyll meter (SPAD-502 plus, Konica Minolta sensing, Inc., Tokyo, Japan). Based on the assumption that initial angles of rotated leaf blades (about $180^{\circ}$ ) can be changed into the form of revolved leaf blades (i.e., less than $180^{\circ}$ ) owing to wind flow as commonly observed in natural wetlands (Haslam 1972), angles between consecutive leaf blades from the uppermost tip to the basal part of each culm were measured as a geometric parameter using a graduated protractor to verify wind-induced physical effects on $P$. australis (Fig. 6). We determined leaf blade number and length by measuring all leaf blades including the uppermost leaf blade on each culm using a ruler stick.

\section{Culm functional traits}

As culm functional traits, we measured internode number and length, culm diameter, mean culm height, and maximum culm height. To determine these functional traits, we also selected randomly five culms from each experimental plot. Internode length and culm height (from the tip of the uppermost leaf blade to soil surface) were measured using a ruler tape. Culm diameter was measured at the basal height of each culm using a vernier calipers. All culm functional traits only except the maximum culm height were measured once at the end of the experiment. In the case of the maximum culm height, we have monitored the values every week for 18

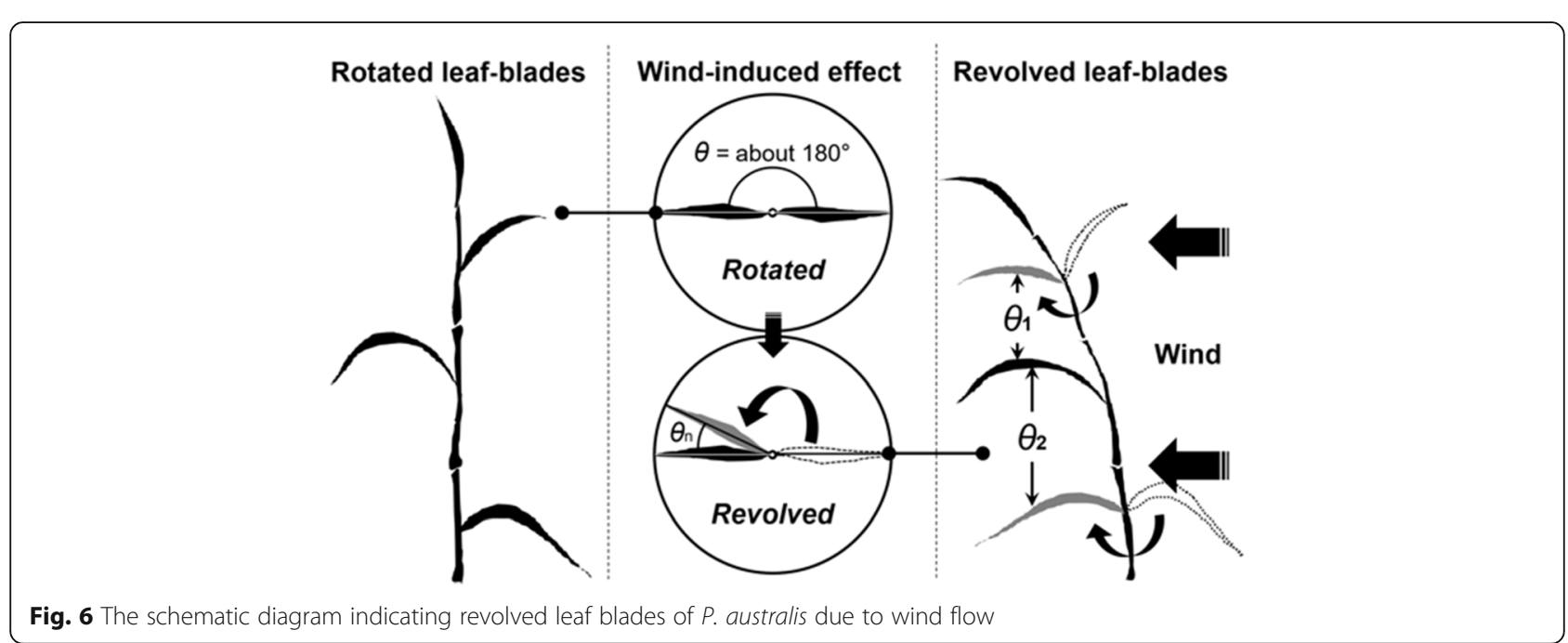


weeks from late May to late September on which most height values began to decrease owing to temperature drop in September (Fig. S1).

\section{Biomass production traits}

For determining biomass production, at the end of the experiment, we harvested all plants and separated them into above- and below-ground parts. We washed belowground parts to remove non-plant materials and separated them into rhizomes and roots. All plant materials were dried in a drying oven under $75^{\circ} \mathrm{C}$ for $48 \mathrm{~h}$.

\section{Statistical analysis}

We performed two-way ANOVA (analysis on variance) and Duncan's post hoc test on the functional traits of leaf blades, culms, and biomass production using the statistical software, SPSS package for Windows (IBM SPSS Version 22.0, USA).

\section{Supplementary Information}

The online version contains supplementary material available at https:/doi. org/10.1186/s41610-021-00184-z.

Additional file 1: Table S1. Physico-chemical characteristics of soil sub-

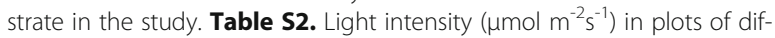
ferent experimental conditions. Figure S1. Air temperature in the greenhouse during the experimental period.

\section{Acknowledgements}

Not applicable.

\section{Authors' contributions}

MGH conceived the study and wrote the manuscript. BEN installed the experimental sets and gathered data. JGK gave conceptual advices and edited the manuscript. The author(s) read and approved the final manuscript.

\section{Funding}

This research was supported by Basic Science Research Program through the National Research Foundation of Korea (NRF) funded by the Ministry of Education (NRF-2015R1D1A1A01057373) and by the National Research Foundation of Korea (NRF) grant funded by the Korean government (Ministry of Science and ICT) (NRF-2018R1A2B2002267).

\section{Availability of data and materials}

The datasets used and/or analyzed during the current study are available from the corresponding author on reasonable request.

\section{Declarations}

Ethics approval and consent to participate

Not applicable.

\section{Consent for publication}

Not applicable.

\section{Competing interests}

The authors declare that they have no competing interests.

\section{Author details}

${ }^{1}$ Department of Science Education, Gwangju National University of Education, Gwangju 61204, Republic of Korea. ${ }^{2}$ Department of Biology Education, Seoul National University, Seoul 08826, Republic of Korea. ${ }^{3}$ Center for Education Research, Seoul National University, Seoul 08826, Republic of Korea.
Received: 25 March 2021 Accepted: 22 April 2021

Published online: 03 May 2021

\section{References}

Ágoston-Szabó E, Dinka M. Decomposition of Typha ansgustifolia and Phragmites australis in the littoral zone of a shallow lake. Biologia. 2008;63(6):1104-10. https://doi.org/10.2478/s11756-008-0154-4.

Amsberry L, Baker MA, Ewanchuk PJ, Bertness MD. Clonal integration and the expansion of Phragmites australis. Ecol Appl. 2000;10(4):1110-8. https://doi. org/10.1890/1051-0761(2000)010[1110:CIATEO]2.0.CO;2.

Armstrong J, Afreen-Zobayed F, Blyth S, Armstrong W. Phragmites australis: effects of shoot submergence on seedling growth and survival and radial oxygen loss from roots. Aquat Bot. 1999;64(3-4):275-89. https://doi.org/10.1 016/S0304-3770(99)00056-X.

Armstrong J, Armstrong W. A convective through-flow of gases in Phragmites australis (Cav.) Trin. ex Steud. Aquat Bot. 1991;39(1-2):75-88. https://doi.org/1 0.1016/0304-3770(91)90023-X

Armstrong J, Armstrong W, van der Putten WH. Phragmites die-back: bud and root death, blockages within the aeration and vascular systems and the possible role of phytotoxins. New Phytol. 1996;133(3):399-414. https://doi. org/10.1111/j.1469-8137.1996.tb01907.x.

Asaeda T, Hietz P, Tanaka N, Karunaratne S. Seasonal fluctuations in live and dead biomass of Phragmites australis as described by a growth and decomposition model: implications of duration of aerobic conditions for litter mineralization and sedimentation. Aquat Bot. 2002;73(3):223-39. https://doi.org/10.1016/S03 04-3770(02)00027-X

Asaeda T, Karunaratne S. Dynamic modelling of the growth of Phragmites australis: model description. Aquat Bot. 2000;67(4):301-18. https://doi.org/10.1 016/S0304-3770(00)00095-4

Baker CJ, Stering M, Berry P. A generalized model of crop lodging. J Theor Biol. 2014;363:1-12. https://doi.org/10.1016/j.jtbi.2014.07.032.

Baldi A. Microclimate and vegetation edge effects in a reedbed in Hungary. Biodiv Conserv. 1999;8(12):1697-706. https://doi.org/10.1 023/A:1008901514944

Baldi A. The importance of temporal dynamics of edge effect in reedbed design: a 12-year study on five bird species. Wetl Ecol Manag. 2005;13(2):183-9. https://doi.org/10.1007/s11273-004-0313-5.

Belzile F, Labbe J, LeBlanc M-C, Lavoie C. Seeds contribute strongly to the spread of the invasive genotype of the common reed (Phragmites australis). Biol Invasions. 2010;12(7):2243-50. https://doi.org/10.1007/s10530-009-9634-x.

Brisson J, Paradis E, Bellavance M-E. Evidence of sexual reproduction in the invasive common reed (Phragmites australis subsp. australis; Poaceae) in eastern Canada: a possible consequence of global warming? Rhodora. 2008; 110(942):225-30. https://doi.org/10.3119/07-15.1.

Clevering OA, Brix H, Lukavska J. Geographic variation in growth responses in Phragmites australis. Aquat Bot. 2001;69(2-4):89-108. https://doi.org/10.1016/ S0304-3770(01)00132-2.

Clevering OA, Lissner J. Taxonomy, chromosome numbers, clonal diversity and population dynamics of Phragmites australis. Aquat Bot. 1999;64(3-4):185-208. https://doi.org/10.1016/S0304-3770(99)00059-5.

Emery RJN, Reid DM, Chinnappa CC. Phenotypic plasticity of stem elongation in two ecotypes of Stellaria longipes: the role of ethylene and response to wind. Plant Cell Environ. 1994;17(6):691-700. https://doi.org/10.1111/j.1365-3040.1 994.tb00161.x.

Engloner Al. Structure, growth dynamics and biomass of reed (Phragmites australis): a review. Flora. 2009;204(5):331-46. https://doi.org/10.1016/j.flora.2 008.05.001.

Hansson L-A, Graneli W. Effects of winter harvest on water and sediment chemistry in a stand of reed (Phragmites australis). Hydrobiologia. 1984; 112(2):131-6. https://doi.org/10.1007/BF00006917.

Haslam SM. The development of the annual population in Phragmites communis Trin. Ann Bot. 1969;34:571-91.

Haslam SM. Phragmites australis Trin. (Arundo phragmites L., ? Phragmites australis (Cav.) Trin. ex Steudel). J Ecol. 1972;60(2):585-610. https://doi.org/10.2307/22 58363.

Haslam SM. The performance of Phragmites communis Trin. in relation to temperature. Ann Bot. 1975;39(4):883-8. https://doi.org/10.1093/oxfordjourna Is.aob.a085006.

Haslam SM. Early decay of Phragmites thatch: an outline of the problem. Aquat Bot. 1989;35(1):129-32. https://doi.org/10.1016/0304-3 770(89)90073-9 
Hong MG, Kim JG. Growth characteristics of cutting culms sectioned at different positions from three reed population. J Korean Soc Environ Res Technol. 2012;15:53-62.

Hong MG, Kim JG. Role and effects of winter buds and rhizome morphology on the survival and growth of common reed (Phragmites australis). Paddy Water Environ. 2014;12(Supp.1):S203-9.

Hong MG, Nam BE, Kim JG. Vegetation and water characteristics of floating mat in a coastal lagoon as the habitat for endangered plant species. J Ecol Environ. 2018;42(1):28. https://doi.org/10.1186/s41610-018-0090-3.

Hong MG, Nam BE, Kim JG. Differences in functional traits of leaf blade and culm of common reed in four habitat types. J Ecol Environ. 2019;43(1):12. https:// doi.org/10.1186/s41610-019-0113-8.

Hughes AR, Schenck FR, Bloomberg J, Hanley TC, Feng D, Couhier TC, et al. Biogeographic gradients in ecosystem processes of the invasive ecosystem engineer Phragmites australis. Biol Invasions. 2016;18(9):2577-95. https://doi. org/10.1007/s10530-016-1143-0.

Jaffe MJ, Forbes S. Thigmomorphogenesis: the effect of mechanical perturbation on plants. Plant Growth Regul. 1993;12(3):313-24. https://doi.org/10.1007/ BF00027213.

Karstens S, Jurasinski G, Glatzel S, Buczko U. Dynamics of surface elevation and microtopography in different zones of a coastal Phragmites wetland. Ecol Eng. 2016;94:152-63. https://doi.org/10.1016/j.ecoleng.201 6.05.049.

Karunaratne S, Asaeda T, Yutani K. Growth performance of Phragmites australis in Japan: influence of geographic gradient. Environ Exp Bot. 2003;50(1):51-66. https://doi.org/10.1016/S0098-8472(02)00114-4.

Klimeš L, Klimešova J, Čižková H. Carbohydrate storage in rhizomes of Phragmites australis: the effects of altitude and rhizome age. Aquat Bot. 1999;64(2):10510. https://doi.org/10.1016/S0304-3770(99)00016-9.

Klötzli F. Über Belastung und Produktion in Schilfröhrichten. Verh Ges Ökol Saarbrücken. 1973;1973:237-47.

Köbbing JF, Thevs N, Zerbe S. The utilisation of reed (Phragmites australis): a review. Mires Peat. 2013;13:1-14.

Lessmann JM, Brix H, Vauer V, Clevering OA, Comin FA. Effect of climatic gradients on the photosynthetic responses of four Phragmites australis populations. Aquat Bot. 2001;69(2-4):109-26. https://doi.org/10.1016/S0304-3 770(01)00133-4.

Liu B, Liu Z, Wang L, Wang Z. Responses of rhizomatous grass Phragmites communis to wind erosion: effects on biomass allocation. Plant Soil. 2014; 380(1-2):389-98. https://doi.org/10.1007/s11104-014-2104-y.

Murren CJ, Pigliucci M. Morphological responses to simulated wind in the genus Brassica (Brassicaceae): allopolyploids and their parental species. Am J Bot. 2005;92(5):810-8. https://doi.org/10.3732/ajb.92.5.810.

Nam BE, Kim JG, Hong MG. Vegetation and water characteristics of an eco-technological water purifying biotope in Yongin. J Wetl Res. 2018; 20:432-45.

Nam BE, Park Y-J, Gil K-E, Kim J-H, Kim JG, Park C-M. Auxin mediates the touchinduced mechanical stimulation of adventitious root formation under windy conditions in Brachypodium distachyon. BMC Plant Biol. 2020;20(1):335. https://doi.org/10.1186/s12870-020-02544-8.

Nilsson C, Gardfjell M, Grelsson G. Importance of hydrochory in structuring plant communities along rivers. Can J Bot. 1991;69(12):2631-3. https://doi.org/1 $0.1139 / \mathrm{b} 91-328$

Saltonstall K. Cryptic invasion by a non-native genotype of the common reed, Phragmites australis, into North America. Proc Nat Acad Sci USA. 2002;99(4): 2445-9. https://doi.org/10.1073/pnas.032477999.

Soons MB. Wind dispersal in freshwater wetlands: knowledge for conservation and restoration. Appl Veg Sci. 2006;9(2):271-8. https://doi.org/10.1111/j.1 654-109X.2006.tb00676.x.

Takeda S, Kurihara Y. The effects of the reed, Phragmites australis (Trin.), on substratum grain-size distribution in a salt marsh. J Oceanogr Soc Jpn. 1988; 44(3):103-12. https://doi.org/10.1007/BF02302617.

Thompson DJ, Shay JM. The effects of fire on Phragmites australis in the Delta marsh, Manitoba. Can J Bot. 1985;63(10):1864-9. https://doi.org/10.1139/ b85-261.

Vymazal J. Plants used in constructed wetlands with horizontal subsurface flow: a review. Hydrobiologia. 2011;674(1):133-56. https://doi.org/10.1007/s10750011-0738-9.

Whitehead FH, Luti R. Experimental studies of the effect of wind on plant growth and anatomy: I. Zea mays. New Phytol. 1962;61(1):56-8. https://doi.org/1 0.1111/j.1469-8137.1962.tb06273.x.
Zhou L, Zhou G, Liu S, Sui X. Seasonal contribution and interannual variation of evapotranspiration over a reed marsh (Phragmites australis) in Northeast China from 3-year eddy covariance data. Hydrol Process. 2010;24(8):1039-47. https://doi.org/10.1002/hyp.7545.

\section{Publisher's Note}

Springer Nature remains neutral with regard to jurisdictional claims in published maps and institutional affiliations.
Ready to submit your research? Choose BMC and benefit from:

- fast, convenient online submission

- thorough peer review by experienced researchers in your field

- rapid publication on acceptance

- support for research data, including large and complex data types

- gold Open Access which fosters wider collaboration and increased citations

- maximum visibility for your research: over $100 \mathrm{M}$ website views per year

At BMC, research is always in progress.

Learn more biomedcentral.com/submissions 